\title{
Mentorship Programmes within the Small and Medium Sized Contractor Development Programme: A Case Study of the Free State Province, South Africa
}

\author{
Godfrey Mofokeng, Wellington Didibhuku Thwala* \\ University of Johannesburg, Johannesburg, South Africa \\ *didibhukut@uj.ac.za
}

\begin{abstract}
The South African government has been implementing various small and medium sized contractor development programmes in an effort to redress the legacy created by apartheid government. The programmes fulfil such an objective through awarding construction projects to the historically disadvantaged Black contractors to enable them develop competent skills, build viable construction firms, create jobs and redistribute wealth. A mentorship programme was put in place to assist the contractors with technical, managerial, contractual and business impediments they might be encountered in the project execution and in running the construction business. The main aim of the paper was to conduct an evaluation of the contractor development mentorship programme in South Africa using the Free State Province as a case study. Questionnaires were distributed to 120 small and medium contractors in the Free State Province, and a review of literature was undertaken. Financial factors were found to be amongst the leading causes of contractors' failures. It was also established that educational qualification and experience in the construction industry have an effect in a contractor's failure or success. A lot of contractors revealed that they were not exposed to the Contractor Development Programmes like in other provinces hence $74 \%$ did not participate in any contractor development programmes and only $26 \%$ did participate. The paper concluded with recommendations on how mentorship within the contractor development programme can be improved.
\end{abstract}

Keywords: Contractor, programme, mentorship, mentors, small and medium size contractors

\section{Introduction}

The construction industry has unique characteristics that sharply distinguish it from other sectors of the economy. It is fragmented, very sensitive to the economic cycles and political environment. It also has a significantly high rate of business failure (Enshassi, Al-Hallaq and Mohamed, 2006). The South African construction industry is an industry that is increasingly becoming more complex in terms of growth which is caused by the amount of investments made by the public and the private sectors in constructions projects. The industry's fortunes tend to fluctuate with the general economy, and it has a cyclical nature and quick response to the changes in the economy (Enshassi, Al-Hallaq and Mohamed, 2006). Therefore Construction Industry Development Board of South Africa (CIDB) saw that there was compelling need to unlock growth constraints and to develop sustainable contracting capacity, as well as to elevate development of previously disadvantaged individuals and enterprises. Leadership by government was required to establish the framework for contractor development. This framework aimed to unlock growth constraints and stimulate the role of industry and stakeholders for skills development, meaningful empowerment and improved contractor performance. Ogunlana et al., (1996) stated that the industry's problems in developing economies can be categorized into three areas: (1) problems of shortages or inadequacies in industry infrastructure, (2) problems caused by clients and consultants, and (3) problems caused by contractor's incompetence/inadequacies. Therefore the mentorship and contractor development programmes will enable the small and medium contractors to develop competent skills, build viable construction business and create jobs. This will ensure that they overcome the challenges faced by other small and medium contractors in developing countries by giving them technical, managerial, contractual and business impediments in running the construction business (Thwala and Mofokeng, 2012).

Purpose of the Paper: The main objective of this paper is to investigate the factors that cause failure and strategies used by small and medium-sized contractors in countering the challenges. The paper also identifies what development and mentorship programmes are in place to support small and mediumsized contractors and how they are implemented. 
Problem Statement: The problem statement to be addressed is the high failure rate among small and medium sized construction companies in South Africa. Statistics South Africa (2005) states that from 1995 to 2005, about 5907 construction companies were formally liquidated. The CIDB (2004) also highlighted that more than 1,400 construction companies were liquidated over the past three years. The National Department of Public Works in partnership with the CIDB saw that there was a need to enhance the capacity and promote equity ownership across the different contracting categories and grades, as well as improving skills and performance in the delivery of capital works and maintenance across the public sector through the National Contractor Development Programme (NCDP). The Free State Province was used as a case study, were the majority of the companies in the Free State Province are companies that are not older than 10 years. This means that there is not much of experience involved within the company, therefore the management or the executive team (which includes the Owner, the CEO, Contracts Director, Financial Manager, Project Manager and the Construction Manager) is often faced with difficult situations which need great experience to tackle them. However the companies that was also young in their existence but with relevant experienced team members from either working at other companies for a long period of time or having a tertiary qualification or a combination of both can be an exception. Therefore can it be said that causes such as managerial, financial, expansion, and environmental are the ones that cause companies to fail?

Limitations: The paper concentrated mainly on small and medium sized contractors in the Free State Province that were listed as suspended, inactive or deregistered on the CIDB contractor register. The study did not look at the whole Free State Province but rather the main towns which had a broad sample of these contractors. Being an outsider was also limiting to what was revealed, especially during observations.

\section{Literature Review}

Small and Medium construction companies play an important role in the South African economy. For example at the end of June 2007, the total number of employees in the construction industry was 543686 and large enterprises employed 35.6\% (193 786) of the workers in the construction industry, followed by the micro enterprises employing 30.8\% (167 620) and an increase of 24\% in the last quarter of 2007 (Stats SA, 2007). In addition to earlier statements, recent studies have found out that despite their significance, small and medium contractors are faced with the threat of failure with statistics indicating that three out of five fail within the first few years (Thwala and Phaladi, 2009). According to Thwala and Phaladi (2009) lack of effective management during their early stages is a major cause of business failure for small and medium sized contractors and some key features of small-scale contractors are that they are largely unregistered, operate in informal sector of the economy and have very little formal business systems. The National Department of Public Works in partnership with the CIDB saw that there was an urgent need to tackle the high failure rate amongst these contractors as minister Sigcau was quoted about their failure rate. This brought about the NCDP, a sector-specific to intervene within the framework of South Africa's Accelerated and Shared Growth Initiative (AsgiSA) (CIDB Status Quo Report, 2009). Led by the Minister of Public Works and the Provincial MECs, it was committed to the acceleration of growth within the construction industry to meet rising national demand. Specifically, the NCDP was geared to address enhancing capacity and equity ownership across the different contracting categories and Grades, as well as improved skills and performance in the delivery of capital works and maintenance across the public sector (CIDB Status Quo Report, 2009)

Thwala and Phaladi (2009) also stated that these challenges include, amongst others, the lack of resources for training contractors, such as funds, poor construction procurement systems and lack of management capacity and resources to equip managers to operate their business enterprises effectively and efficiently. The National Department of Public Works Contractor Incubator Programme (NDPW CIP) aimed at addressing the challenges the contractors had and ran over a three year cycle, and focused on the development of contractors in CIDB Grades 3 to 7 (CIDB Status Quo Report, 2009). The purpose of the Programme was to create an enabling environment within which qualifying existing contracting enterprises can develop. The Programme included focused supply side support through a structured mentorship-centred enterprise development programme. The NDPW CIP has an established regulatory framework to support contractors, and the business processes of the NDPW CIP are also aligned to the preferential procurement policy and the Public Finance Management Act (PFMA). The NDPW CIP business process model allows for the targeting of categories defined by the Department as blacks, women, youth and the disabled (CIDB Status Quo Report, 2009). In addition, the relative lack of success 
facing emerging contractors in South Africa was discussed by (Rwelamila, 2002). International Labour Organization -ILO- (1987); as follows: Inadequate finance and inability to get credit from suppliers; Inability to employ competent workers; Poor pricing, tendering, and contract documentation skills; Poor mentoring; and fronting for established contractors; Lack of entrepreneurial skills; Lack of proper training; Lack of resources for either large or complex construction work; Lack of technical, financial, contractual, and managerial skills; and late payment for work done (Thwala and Phaladi, 2009).

Managerial Factors: Experience in any kind of management is very important and it plays a crucial role in ensuring that a business succeeds or fails. Poor management has been posited as one of the main causes of failure of small enterprises (Longenecker, et al., 2006) Lack of experience in the constructions industry can lead the manager to make bad business decisions. A greater percentage of emerging contractors cannot perform cash flow projections. Work stoppages are encountered due to lack of financial planning. A number of projects are characterized by shortage of materials, contractors not observing time frames set for completing tasks, contractors not fulfilling contracts with the labourers, disputes between contractors and labourers over the agreed wage, and the delays in payment of labour due to cash flow problems. Dlungwana and Rwelamila (2003) stated that training and mentorship needs are identified, based on the results of the assessment exercise, and an appropriate training and mentorship intervention is developed. Training and mentorship revolves around the contractor's business management skills and knowledge, such as tendering and marketing, thus affording SMEs an opportunity to gain basic capability or, more importantly, a competitive edge in comparison to their counterparts. The authors stated that the benefits that construction industries reap for developing their contractors include, among others, sustainable, competitive enterprises that deliver better products and create growth and employment. Good management implies an awareness of all factors making up a successful business namely good strategy, marketing, pricing and financial control. Financial mismanagement and management incompetence have been cited among the attributes that lead to the prominence of construction failures (Kangari, 1988).

Financial Factors: The high competition among emerging contractors has contributed to increase financial failures of the emerging market, making the market unsustainable (Thwala and Mvubu, 2008). Financial Management is the key, which determines business growth. The most prominent causes of failure with construction companies' results from inadequate cash resources and failure to convince creditors of the availability of money. Thwala and Mvubu, (2008) concurs with this view that even profitable firms could be forced into liquidation, because the demand for payment or settlement of outstanding accounts could not be met at the critical time despite the fact that the assets are tied in longterm investments. Emerging contractors have an uphill battle in financing their projects. The housing subsidy is only paid out to the builder on a reimbursement basis. Contractors have to use their capital to purchase material and build the top structures before they access the subsidy. Furthermore, capital is often required to smoothen out the strains on the cash flow resulting from the occurrence of cost and uncertainty. Lack of access to finance both during pre-construction which disqualifies emerging contractors from meeting guarantee and performance bond requirements and during construction which leads to cash-flow problems, incomplete work and even liquidation are financial constraints facing emerging contractors able (Thwala and Mvubu, 2008).

Mentorship in the construction industry: According to the South African Department of Public Works Code of Practice (2001), a mentor is a trusted and respected advisor. It further defines that construction mentors, based on their knowledge, gained through practical experience and prior learnt skills in the construction industry, is able to:

- Guide and advice emerging contractors in the areas in which they need to improve their competencies

- Develop the managerial skills of the key staff members in the business in the functional areas of administration and information technology, public relations, procurement, finance, human resources, marketing and technical skills

- Set up business systems in emerging companies

According to the South African Department of Public Works Code of Practice, mentorship, in one form or another, has existed in the construction industry for centuries. In South Africa, mentorship has been identified as a means of developing capacity in new entrants to the construction sector and overcoming business impediments in existing firms that have arisen as a result of the legacies of apartheid. It aims to achieve this goal through the coordinated and controlled transfer of knowledge and experience with the 
help of mentors who are responsible for giving reliable and honest advice to the person being mentored (South Africa, Department of Public Works, 2001).

The most common approach to contractor development used by a number of countries is the registration of contractors. While most countries do not use the registers as a tool for managing the performance of contractors, there is clear evidence of benefits to those which do. Proper use of the registers enables public sector clients to manage contractor risk on their projects and to monitor contractor progression based on accurate information (Dlungwana and Rwelamila, 2003). The best practices on the effective use of registers were found in Australia, Singapore and Malaysia. The South African Department of Public Works Code of Practice adds that mentorship involves the transfer of knowledge and experience, but excludes the performance of essential daily contracting functions on behalf of the mentored contractor. Mentorship is essential to accelerate the process of empowerment. It affords emerging contractors, who are awarded contracts, the benefit of the experience of those individuals who have extensive experience in the construction industry. This exposure is designed to address many of the common shortcomings encountered by emerging contractors, such as poor pricing structures, the winning of non-profitable tenders, late starts to contracts, late submissions of payment claims, late commissioning and the handover of contracts (Department of Public Works, 2001).

\section{Methodology}

The study was conducted with companies that are situated in Welkom, Virginia, Kroonstad, Odendaalsrus, Allanridge, Theunissen, and Hennenman which are towns that are all in the Free State Province. Each town had a minimum of four companies except Welkom and Kroonstad as they are bigger towns with more companies.

\section{Map 1: Map showing the Free State Province}

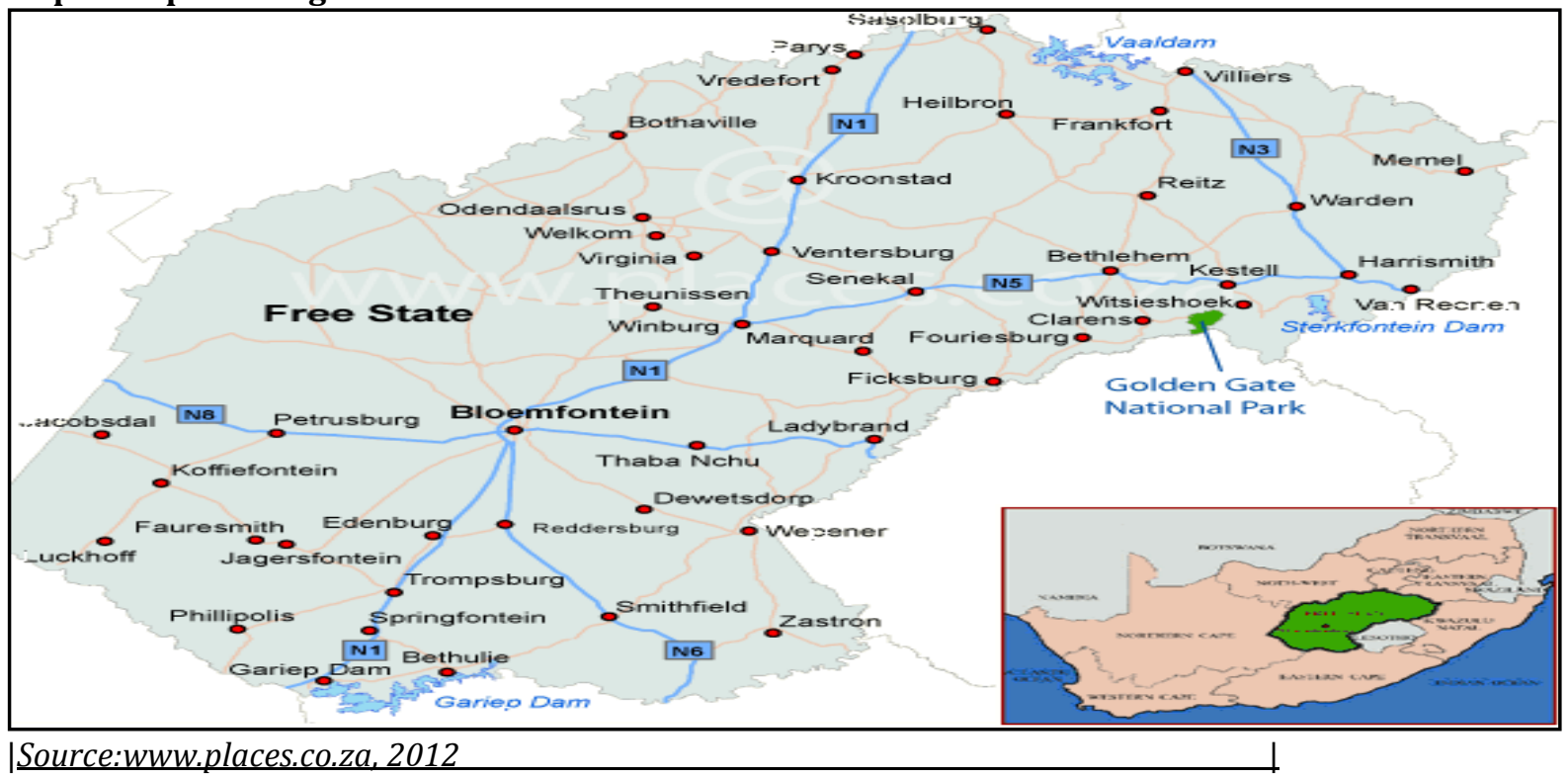

The authors worked as the fieldworkers by undertaking visitations to these companies was over a period of approximately four weeks were the questionnaires were distributed which was the primary source of data collection random verbal conversations took place, and the primary focus was on their management styles in the company and interactions with everyone involved in the company. The primary source of data of this study was done by means of a questionnaire. According to Love, Sing, Wang, Irani, and Thwala (2012) where availability and access to databases and case studies is limited a questionnaire survey can be adopted. The questionnaire method enables the researcher to collect data from large number of potential respondents within a short period and makes a possible quantitative analysis to be much to be done. The population and questionnaire administration was drafted and hand delivered to respective respondents that included company owners and senior manager. The samples were randomly selected from the Construction Industry Development Board (CIDB) list of Expired, Suspend and Deregistered contractors in the Free State Province who met the sample requirements. Some of the requirements were; 
- The contractors had to be from the Free State Province

- The contractors had to be Small, Medium or Micro

- They were expired, suspended or deregistered

By April 2012, the Free State Province had 3197 expired, suspended or deregistered contractors in the CIDB list. A total of 120 questionnaires were randomly distributed, 102 questionnaires were received and 6 questionnaires were spoilt which meant that the total workable questionnaires were 96 which was at a return rate of $80 \%$. The study also focused data was collected by talking to the managers and asking the experiences of running a company as well as the hidden challenges they face on a daily basis as well as finding out if they had attended any of the development programmes that were in place. Reviewing past studies on causes of company failures topics and contractor mentorship programmes around the world and related literatures as well as gathering information through journal articles, internet, and construction magazines was used to gather literature on the topic. Data analysis and identification of the most relevant factors influencing causes of contractor failures were the primary and secondary sources as well development programmes. The author then wrote a report that combined the relevant theory and previous research with the results of the practical research done.

\section{Results and Discussion}

The findings provided were in respect of primary objectives of the study which was to investigate the causes of failure among small and medium construction companies as well as assessing the development and mentoring programmes in the Free State Province and some of the possible factors were mentioned in the literature review in chapter two. As the problem statement brought it to light that there is a high failure rate of small and medium construction companies in the industry, the analysis will therefore provide evidence that there is indeed a high company failure rate and in the Free State Province in this regard and the possible causes. Based on the first objective of the study "to investigate the factors that cause failure amongst small medium contractors in the Free State Province" financial factors were found to be amongst the leading causes of company failures, whereby 43 respondents in the questionnaire said that Not Getting Enough was one of the main causes while 37 respondents said Lack of finance or enough money to run a business. A total of 34 respondents said that Late Payments from Clients was a contributing factor as well as financial mismanagement for personal usage and 27 Managerial skills \& bad leadership with 31 and 27 mentions respectively. The response from the questionnaire also showed that the companies did not have adequate cost and accounting practices and systems in place which also affected the estimating and procurement systems to be done properly and efficiently. The long periods it took the clients to pay the contractors were detrimental because it also affected the whole companies' cash flow to be in a negative state. The researchers also established from talking to the different managers that the use of company finance for personal usage was also common amongst small companies because these companies are not always audited and it was easier for them to use and therefore the companies suffered in that regard.

Figure 1: The cost and accounting systems adequacy in the companies

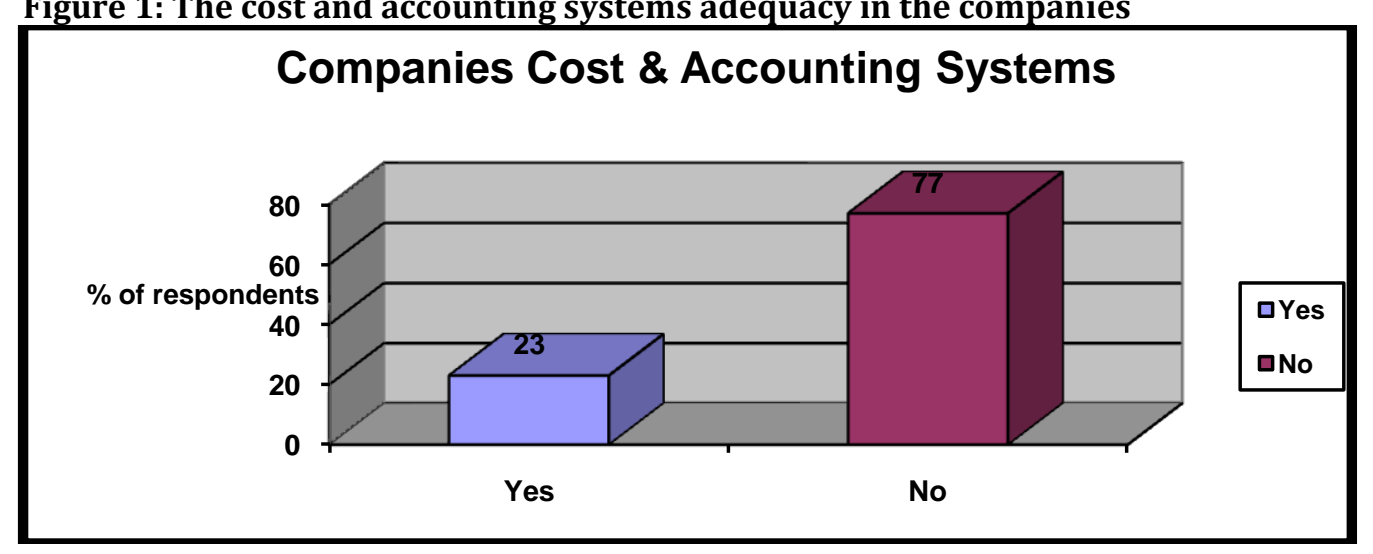

It is of vital importance that any company, whether small or large that it has got proper cost and accounting systems in place because it is where the companies' finances are directed. $77 \%$ of the respondents said that their companies did not have adequate cost and accounting systems in place while the other $23 \%$ said that their companies did have adequate cost and accounting systems in place. From 
the $77 \%$ who said that they did not have, they said it was because they could not afford it and were a small company. The $23 \%$ that said they did have, said they had a designated department within the company.

Figure 2: The respondents' highest educational qualification

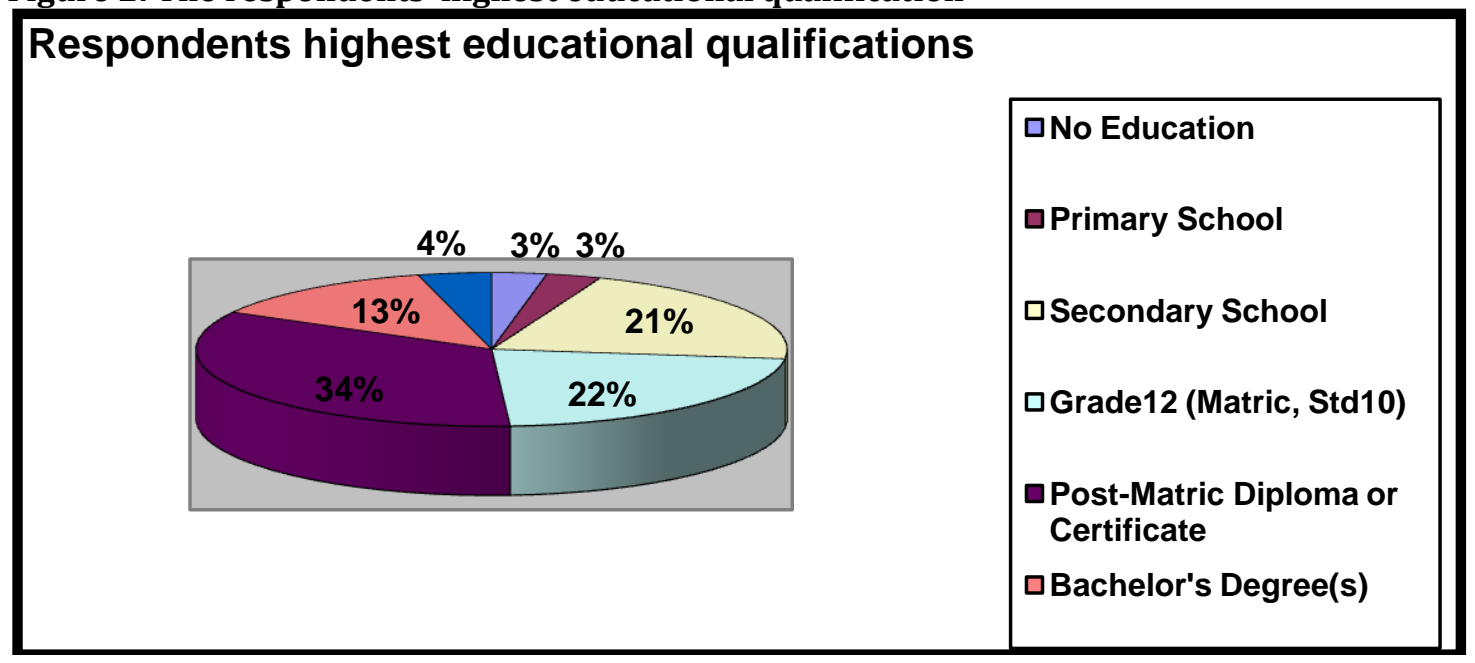

It is anticipated that the higher the level of small and medium contractors' education the more skills they will have in managerial positions. Notably the small and medium contractors mostly hold matric certificates and post matric diplomas or certificates. These comprise more than half of the population sample with post matric diploma or certificate making up 34\%. It was followed by matric qualifiers at $22 \% .21 \%$ is of those who have secondary school education, $13 \%$ hold a bachelors degree, while $4 \%$ have post bachelor's degrees. Evidently this is a group of educated people hence the assumption is that they are aware of methods of running a company in relation with experience. It is expected that the small and medium contractors should have qualifications in construction in order to run their businesses. Only 3\% of the respondents have an education of primary school or no education.

Figure 3: The respondents' number of years within the construction industry

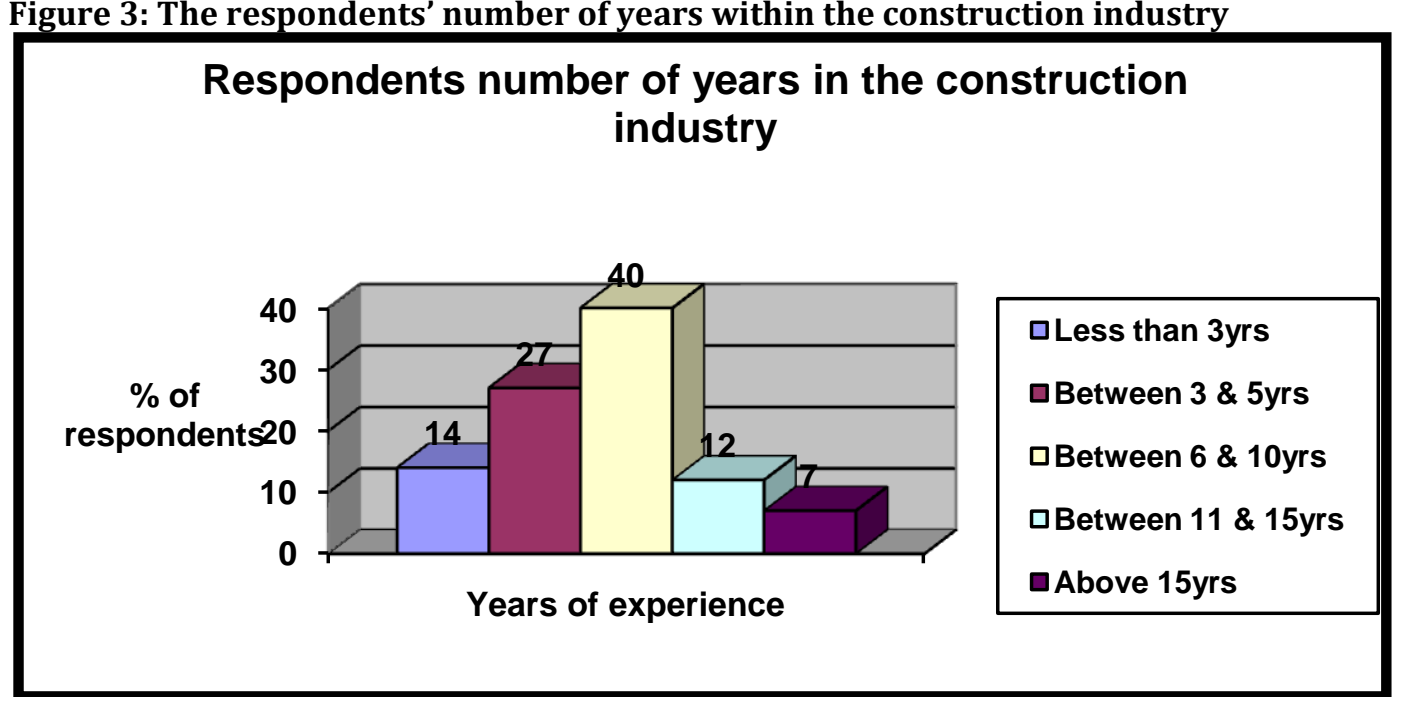

In every industry it is important to have experience for the role to be performed to excellence. The majority of the respondents are people who have a lot of experience in the industry which they acquired from working for other companies and then decided to go and establish their own companies. $40 \%$ of the respondents had experience of between 6 years and 10 years, followed by 3 years and 5 years at $27 \%$. $14 \%$ of the respondents had less than 3years and 12\% had experience between 11 years and 15 years in the industry while $7 \%$ had been in the industry for more than 15 years. In the open ended questions there were common responses which were mentioned by a majority of the respondents were categorized according to their similarity and the number of times they were mentioned was showed as follows: 


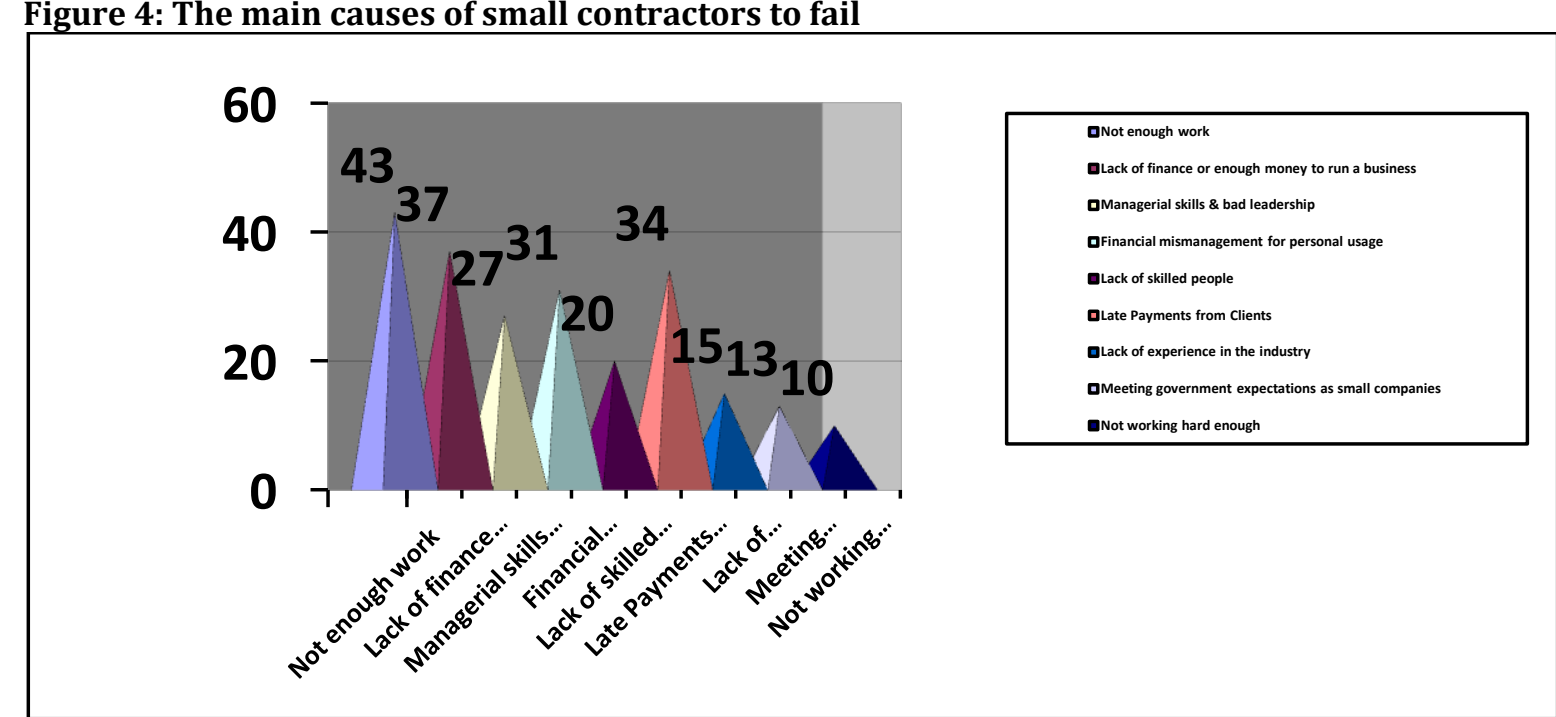

When asked about the main causes of small contractors to fail in the open ended questions, most respondents reported that Not Getting Work was the greatest contributor to causes of contractors to fail, and 43 of the respondents (which is $50 \%$ of the total respondents) correlated in that statement, 37 of the respondents said that Lack Of Finance or Enough Money to Run a Business, 27 said Managerial Skills \& Bad Leadership. 31 respondents said Financial Mismanagement for Personal Usage whereby the owners of the companies would use substantial amounts for personal usage before the project would be complete. 15 of the respondents said Lack of Experience in the industry, and 20 said that Lack of Skilled People. 10 respondents said not working hard enough while 13 said Meeting Governments Expectations as Small Companies. 34 respondents said Late Payments from Clients especially the Free State Department of Human Settlements, contributed to the main causes of small contractors to fail.

In the likert scale of 1 - 5 the researcher developed an index Challenge \& Problem Index (CPI) to analyze the responses in a statistical method in question 17 , it is explained as follows:

$\mathrm{CPI}=$

$$
\left(1 \alpha_{1}\right)+\left(2 \alpha_{2}\right)+\left(3 \alpha_{3}\right)+\left(4 \alpha_{4}\right)+\left(5 \alpha_{5}\right)
$$

$$
\sum \alpha
$$

$(1)=$ To no extent, $(2)=$ To small extent, $(3)=$ Moderate, $(4)=$ To large extent,

(5) = To very large extent...

$\alpha=$ Number of responses

$\sum_{\alpha}=$ Total responses per variable

The Challenge \& Problem Index (CPI)

\begin{tabular}{|c|c|c|c|c|c|c|c|}
\hline & $\begin{array}{l}\text { To no } \\
\text { extent }\end{array}$ & $\begin{array}{c}\text { To small } \\
\text { extent }\end{array}$ & Moderate & $\begin{array}{c}\text { To } \\
\text { large } \\
\text { extent }\end{array}$ & $\begin{array}{c}\text { To very } \\
\text { large } \\
\text { extent }\end{array}$ & $\begin{array}{c}\text { CPI } \\
\text { Weighting }\end{array}$ & Rank \\
\hline Lack of cash flow & 2 & 6 & 11 & 10 & 67 & 4.40 & 1 \\
\hline Lack of Financial Management & 6 & 9 & 10 & 11 & 60 & 4.15 & 2 \\
\hline Lack of skilled people & 3 & 12 & 13 & 9 & 59 & 4.14 & 3 \\
\hline Deficiency in Tendering & 6 & 9 & 10 & 9 & 62 & 4.12 & 4 \\
\hline Lack of business management & 5 & 13 & 12 & 8 & 58 & 4.05 & 5 \\
\hline Lack of estimating & 6 & 16 & 11 & 8 & 55 & 3.94 & 6 \\
\hline Lack of marketing & 7 & 18 & 10 & 8 & 53 & 3.85 & 7 \\
\hline Lack of project planning & 9 & 18 & 12 & 8 & 49 & 3.73 & 8 \\
\hline $\begin{array}{l}\text { Lack of implementation of } \\
\text { Health and safety issues }\end{array}$ & 13 & 20 & 11 & 7 & 45 & 3.53 & 9 \\
\hline Lack of project administration & 21 & 24 & 15 & 6 & 30 & 3.00 & 10 \\
\hline Lack of communication & 29 & 37 & 18 & 6 & 6 & 2.20 & 11 \\
\hline Lack of delegation & 37 & 33 & 13 & 7 & 6 & 2.08 & 12 \\
\hline Lack of inventory management & 47 & 43 & 3 & 1 & 2 & 1.63 & 13 \\
\hline
\end{tabular}

Table 1: The Challenge \& Problem Index (CPI) 
The second and third objective "to investigate what strategies are employed by small and medium contractors in countering the challenges that they face" \& "What development and mentorship programmes are in place to support the small and medium contractors and how are they implemented". It was found in the open-ended questions in the questionnaire, that the challenges that were encountered can be overcome by participating in development programs and courses that will enhance their skills as well as expediting payments from clients.

Figure 5: The companies that participated in development programs

\section{Company participation in Contractor Development programmes}

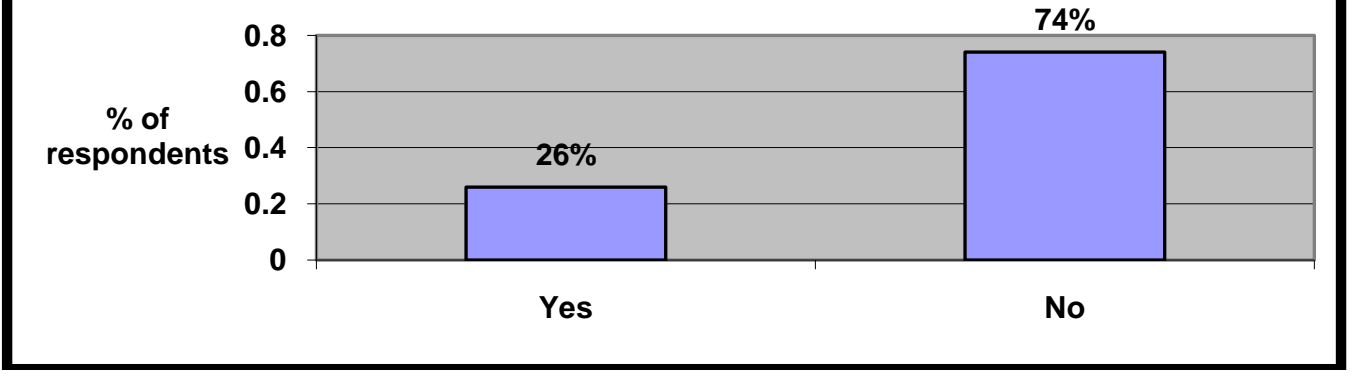

Scholars such as Rwelamila (2002) and Thwala and Phaladi (2008) agree that an outlook of the SME sector in many Southern African construction industries needs serious attention. This situation needs the urgent attention of relevant industry stakeholders such as governments and training and research organisations. A lot of contractors in the Free State province revealed that they were not exposed to the Contractor Development Programmes like in other provinces hence $74 \%$ of them said they did not participate in any development programmes and only $26 \%$ did participate. Various contractors said they did get benefits from the development programmes and the common ones were as follows:

Table 2: Contractor Development Programmes Benefits

\begin{tabular}{|c|c|c|}
\hline Contractor Development Programmes Benefits & $\begin{array}{l}\text { Number } \\
\text { mentioned }\end{array}$ & Rank \\
\hline Becoming innovative \& competent contractors & $11.5 \%$ & 1 \\
\hline Having business sustainability & $9.4 \%$ & 2 \\
\hline Financial control and competitive tendering & $9.4 \%$ & 2 \\
\hline Making partnerships and working together & $7.3 \%$ & 3 \\
\hline $\begin{array}{l}\text { Better Technical \& Business understanding of the } \\
\text { construction commerce. }\end{array}$ & $5.2 \%$ & 4 \\
\hline Ability to identifying Risk vs. Opportunity better & $4.2 \%$ & 5 \\
\hline
\end{tabular}

From the 25 respondents who mentioned that they attended the development programmes, $11.5 \%$ of them said the benefits were that they became innovative in their business and became competent contractors. 9.4\% respondents said they learnt how to sustain their business, 9.4\% respondents also said knowing how to control their companies' finances as well as having the ability to tender competitively. $7.3 \%$ respondents said the benefits were making partnerships with the relevant role players (e.g. government entities, financial institutes, regulatory boards etc) as well as working together with them. $5.2 \%$ respondents said they got a better understanding of the whole industry as well as the technical aspects of running a construction company. $4.2 \%$ respondents mentioned that they could identify risks and opportunities better than before and how to act on each. The contractors also said the development programmes had problems and the common ones were as follows: 
Table 3: Contractor Development Programmes Benefits

\begin{tabular}{|c|c|c|}
\hline Contractor Development Programmes Problems & $\begin{array}{l}\text { Number } \\
\text { mentioned }\end{array}$ & Rank \\
\hline $\begin{array}{l}\text { The programmes were not well publicized for everyone to } \\
\text { know about them }\end{array}$ & 20 & 1 \\
\hline $\begin{array}{l}\text { There is not enough support given to the contractors after } \\
\text { the programmes }\end{array}$ & 12 & 2 \\
\hline Private companies are not involved enough & 9 & 3 \\
\hline $\begin{array}{l}\text { The programmes happen on limited occasions and not } \\
\text { regular enough }\end{array}$ & 8 & 4 \\
\hline $\begin{array}{l}\text { The government does not take responsibility for the growth } \\
\text { \& success of the contractors }\end{array}$ & 6 & 5 \\
\hline Work and funding is not provided by the department & 4 & 6 \\
\hline
\end{tabular}

From the 25 respondents who mentioned that they attended the development programmes, 20 said the programmes available were not well publicized and a lot of contractors did not know about them when they took place. 12 respondents said that there was not enough support given to the contractors after the programmes. 9 respondents said they have only seen government host these programmes without private companies therefore they are not involved enough. 8 respondents said that these programmes do not happen regular enough as they feel they need constant training to hone their skills. 6 respondents and 4 respondents said government did not take responsibility for the growth and success of the contractors as well as providing work and funding respectively. The implementation of development models requires serious commitment, planning and resource allocation by the managers of government agencies, to enable confident entrepreneurs to grow their businesses and create sustainable employment. Without such support, the models cannot effectively address the challenges faced by SME contractors in the construction industries (Dlungwana and Rwelamila, 2003). Appropriate support institutions, such as research organisations, also play a critical role in facilitating learning through knowledge creation and sharing. The responses below were the common solutions which were described by the respondents and they thought should be implemented. How the challenges and problems can be overcome.

Table 4: Challenges and Problems

\begin{tabular}{llc}
\hline Challenges and Problems & $\begin{array}{l}\text { Number } \\
\text { mentioned }\end{array}$ & Rank \\
\hline $\begin{array}{l}\text { By expediting payments from clients and government must } \\
\text { intervene. }\end{array}$ & $34.4 \%$ & 1 \\
$\begin{array}{l}\text { Take part in skills development programmes, workshops \& } \\
\text { courses. }\end{array}$ & $27.1 \%$ & 3 \\
$\begin{array}{l}\text { Government must root out corruption in its department and } \\
\text { transparent tender \& procurement processes. }\end{array}$ & $41.9 \%$ \\
$\begin{array}{l}\text { Tendering more competitively for private jobs and not only } \\
\text { government jobs. }\end{array}$ & $16.7 \%$ \\
$\begin{array}{l}\text { CIDB should reach out to the small contractors and assist them } \\
\text { with getting upgrades. }\end{array}$ & $11.5 \%$ \\
$\begin{array}{l}\text { Small contractors with more skills must merge to have one } \\
\text { skilled company in the industry }\end{array}$ & $9.4 \%$ & 6 \\
\hline
\end{tabular}

Challenges for many small and medium size contractors in the developing countries, caused the forces of globalisation to have resulted in declining market share due to lack of management capacity and resources to equip managers to operate their business enterprises effectively and efficiently (Dlungwana and Rwelamila, 2003). 34.4\% respondents said that the challenges and problems they experienced could be overcome by expediting payments from clients and government must intervene to ensure that they do get paid on time because long periods waiting for payments are a big problem for small and medium contractors. $27.1 \%$ respondents said that taking part in skills development programmes, workshops \& courses will also tackle their challenges and problems they face. $21.9 \%$ respondents said that government must root out corruption within its departments and there must be transparent tender \& procurement 
processes. $16.7 \%$ respondents said tendering more competitively for private jobs and not only government jobs will help as they only tendered for government jobs. $11.5 \%$ respondents said that the CIDB should reach out to the small contractors and assist them with getting upgrades because they are unable to get bigger jobs because they have low CIDB grades. 9.4\% respondents said small contractors with more skills must merge to have one skilled company in the industry because in that way they will be more competitive when tendering and doing projects and this will help overcome the challenges they faced.

\section{Conclusion}

The conclusion drawn by the researcher based on the problem statement is that the majority of small and medium construction companies in the Free State Province lack the managerial skills as well as the financial, environmental and expansion factors. These factors have an effect in the failure of a company and they can be improved and changes can be made in some areas. It was also concluded that there are small and medium contractor development and mentorship programmes available, but a huge majority of these contractors do not have sufficient information about them. In the study it was established that training offered by organisations such as the Construction Education and Training Authority (CETA) is not accessed by the majority of small and medium contractors in the Free State Province are not exposed to these skills development trainings and programmes. The findings have also revealed that the small and medium contractors in the Free State do not get work regularly and that also contributes to the appropriate function of the companies, however the jobs that they do get are just to keep them surviving till the next job comes along. This means that the current state of many of these companies are not healthy because for a construction company to make a profit they need to participate meaningfully in the available construction job market. Innovative partnering relationships between small contractors and large construction enterprises to create a successful situation in how local projects are undertaken should be established within the industry. The support of other industry stakeholders must also be strongly encouraged.

Recommendations: It is recommended that the following are interventions are made:

- The development and mentoring programmes available must be well advertised to all the small and medium contractors as many of them are not aware when they happen.

- Training and development of small and medium contractors in the Free State ranks as the most important intervention at this stage by the Free State government in particular. The procedure must ensure that these contractors as well as emerging contractors will benefit from these development programmes.

- The companies must market themselves more and must not only depend on government jobs but must also tender in the private sector.

- Strict rules and regulations must be put in place for the clients who do not pay the companies in time.

- The registration of small contractors by the Construction Industry Development Board (CIDB) needs to be attached to the contractors' performance and the skills that are improved.

- There must be a body that governs and regulates the construction industry for people who want to enter as construction business by screening them and identifying the possible risks to prevent possibilities of business failure.

- In big government projects, the government must make it compulsory that large contractors need to get into meaningful joint ventures with small and medium contractors to give them worthwhile work and opportunities for long term growth.

\section{References}

Construction Industry Development Board (CIDB). (2004). South African Construction Industry Status Report- Synthesis Review on the South African Construction Industry and its Development: A Discussion Document. CIDB: Pretoria, South Africa.

CIDB. (2009). Strategic Plan, Business Plan and Budget, October.

CIDB. (2010). Framework, National Contractor Development Programme, January.

Department of Public Works. (2001). Code of Practice: Mentorship in Engineering and Construction Works Contracts in South Africa. Pretoria, South Africa.

Dlungwana, W. S. \& Rwelamila, P. D. (2003). The role of performance assessment tools in improving contractor performance in developing countries, CSIR Boutek: Pretoria. 
Enshassi, A., Al-Hallaq, K. \& Mohamed, S. (2006). Causes of Contractor's Business Failure in Developing Countries: The Case of Palestine. Journal of Construction in Developing Countries, 11(2), 1-14.

Kangari, R. (1988). Business failure in constructions industry. Journal of Construction Engineering and Management, 114(2), 172-190.

Love, P. E. D., Sing, C. P., Wang, X., Irani, Z. \& Thwala, D. W. (2012) Overruns in transportation infrastructure projects. Structure and Infrastructure Engineering Journal, 18 (4).

Longenecker, J. G., Petty, C. W., Moore, J. W. \& Palich, L. E. (2006). Small Business Management, An entrepreneurial emphasis. London: Thomson South Western.

Ogunlana, S. O., Promkuntong, K. \& Jearkjirm, V. (1996). Construction delays in a fast-growth economy; comparing Thailand with other economies. International Journal of Project Management, 14(1), 37-45.

Rwelamila, P. D. (2002). African Construction Industries in Turmoil? Implications for Nepad, Proceedings, $1^{\text {st }}$ CIB-WI07 International Conference on Creating a Sustainable Construction Industry in Developing Countries, 11-13 November, Stellenbosch, South Africa.

Statistics South Africa, Statistical release, Construction industry. (2007). Viewed 31 August 2010, <http://www.statssa.gov.za/publications/P5002/P50022007.pdf>

Thwala, W. D. \& Mofokeng, G. (2012). An Exploratory Study of Problems Facing Small and Medium Sized Contractors in the Free State Province of South Africa in Business Dynamics in the 21st Century, (Editors) Chee-Heong Quah and Ong Lin Dar: Slavka; INTEC Publishers.

Thwala, W. D. \& Mvubu, M. (2008). Current Challenges and Problems Facing Small and Medium Size Contractors in Swaziland. African Journal of Business Management, 2(5), 093-098.

Thwala, W. D. \& Phaladi, J. P. (2009). An exploratory study of problems facing small contractors in the North West province of South Africa. African Journal of Business Management, 3(10), 533-539. 